\title{
Development of Edmodo-Based E-Learning Media on the Plantae's Discussion for Learning Biological High School
}

\author{
Ivaturrohmah $^{1}$, Imam Mudakir $^{2}$, Kamalia Fikri $^{3}$ \\ Fakultas Keguruan dan Ilmu Pendidikan, Universitas Jember \\ E-mail: imam_mudakir@yahoo.com
}

\begin{abstract}
Biology is a science whose concept is abstract and has a wide scope. One of them is the subject of Plantae that requires appropriate media to help to visualize the material being taught. Some things to consider in the selection of media such as material and learner characteristics. Characteristics of learners today is known as the $Z$ generation so that the appropriate media is one that involves the use of technology. One of them is Edmodo-based e-learning media. The use of Edmodo-based e-learning media enables the delivery of more varied and much-involved students. This study aimed to find out the development process of Edmodo-based e-learning media and to produce a valid product as well as to know the effectiveness and practicality of the product. This research was a development research using a method by Borg and Gall (1983) model that has been modified by Sugiyono (2006). Stage of limited scale trial was conducted in SMAN 2 Jember and SMAN 4 Jember. The result of the product validation test of e-learning media development on average produced a valid product. Effectiveness test at SMAN 2 Jember and at $S M A N 4$ Jember resulted in a high $N$-Gain score. The result of the practicality test through the students and teachers responses of SMAN 2 Jember and SMAN 4 Jember created a response with strongly agree category.
\end{abstract}

Keywords: Edmodo, e-learning, development, Plantae subject.

\section{INTRODUCTION}

The concepts in biology are characterize for its abstract and quite broad in scope. One of which is the subject of Plantae. Therefore it requires proper visualization in the delivery of material. Learning objectives will be more easily achieved with the help of supportive learning media (Falahudin, 2014).

Based on observations made on several students and teachers at SMAN 1 Jember, SMAN 2 Jember and SMAN 4 Jember, the results showed that the delivery of biology material on the subject of Plantae only uses textbooks or media such as Powerpoints. The use of that particular media is considered less attractive, less involving students and allowing learning to be long, resulting in students becoming bored. This has become one of the problems that exist in biology learning on the subject of Plantae.

The selection of learning media must also be in accordance with the characteristics of students. Adolescents today are known as Generation Z, which is the generation that emerged along with the development of the era of the World Wide Web (www) which has a high adaptation to the use of technology (Seragih, 2012).

One of the media in accordance with the characteristics of the Plantae subject as well as the characteristics of students is Edmodobased e-learning (electronic learning) media. E-learning is an interactive form of distance learning that is carried out with the help of internet media (Suyanto, 2015). While Edmodo is one of the school-based environment networks (school-based environment) (Dwiraharja, 2015). The choice of Edmodo as a learning media is also based on the students' passion in accessing social media on the internet, such as Facebook (Utomo, et.al., 2015).

Researchers who have implemented Edmodo-based e-learning media development products, one of which is Utomo et al. (2015), in his research entitled "Development of Learning Materials based on E-learning Edmodo on the Material of Class X High School Lithosphere". Based on

Bioedukasi Vol. XVI. No. 2 Oktober 2018

Received 8 August 2018 | Received in revised form 7 September 2018 | Accepted 21 September 2018 | Published online 1 October 2018 
some of the considerations above, a research was conducted entitled "Development of Edmodo-based E-learning Media in the Plantae Subject for Biology Learning in High School"

\section{RESEARCH METHOD}

This research was a development research using the development model Borg and Gall (1983) which has been modified by Sugiyono (2006). The first stage was the problem analysis which consists of the library study and field studies at SMAN 1 Jember, SMAN 2 Jember, and SMAN 4 Jember. The second stage was the initial product development, the manufacturing of the product in December 2017. The third stage was expert validation which consists of three phases of validations, namely validation by media experts, validation by material experts and validation by users. The fourth stage was limited scale trials conducted at SMAN 2 Jember on January 24-February 72018 and at SMAN 4 Jember on February 14, 2018.

The population in this study were all students of class $X$ at SMAN 2 Jember and SMAN 4 Jember. While the samples were class X MIPA 7 MAN 2 Jember and $\mathrm{X}$ MIPA 4 SMAN 4 Jember. The effectiveness test uses the design of one group pretest / posttest design which is then analyzed using the N-Gain formula.

\section{RESULT AND DISCUSSION}

This development research used the Borg and Gall (1983) model which has been modified by Sugiyono (2006) into 5 stages. The first stage was problem analysis which divided into two stages, namely the field survey stage to obtain empirical data and the literature study stage to obtain theoretical data. Assessment of the theory must be relevant to the problem and research variables, so the theory is able to explain the results of the study (Djiwandono, 2015).

In the field survey activity, researchers identified several things related to the actual situation in the field, such as the situation in the classroom, at school, or in other settings. Some important things, for example, are the use of media that is inadequate or meets learning needs along with the impact that occurs when the use of the media is inadequate, so researchers seek solutions to be able to meet existing needs in the field (Setyosari, 2013). In this study, the problem analysis was by distributing questionnaires to representatives of class XI students who had studied the biological material in the Plantae subject in class $\mathrm{X}$ and to biology class $\mathrm{X}$ teachers in three schools, which were SMAN 1 Jember, SMAN 2 Jember, and SMAN 4 Jember.

Based on the results of questionnaires, it was known that in biology learning on the subject of Plantae the three schools often used media in the form of textbooks, Powerpoints, and some also used learning videos. Some students stated that the media used did not bother students, but the media was considered less attractive and incomplete. Besides that, the use of media that was less varied and less involving students causes students to tend to feel bored. Media selection is important because the use of these media will cause learning to be more meaningful so that it can improve learning outcomes. Therefore, the use of instructional media that is less suitable will affect the understanding and results of student learning (Susilana, et.al., 2009).

The second stage in this research was the development of initial products based on observation results, needs analysis and theoretical analysis (Irfandi, 2015). At this stage the design of the media, including making a teacher account in Edmodo, designing online classes in Edmodo, designing teaching materials that contained Plantae subject matter, making videos, and making quizzes. Preparation of material in teaching materials and learning videos by considering the applicable curriculum by taking into account basic competencies and learning objectives.

The third stage in this research was conducting validation activities by several experts. The purpose of the validation

\section{Bioedukasi Vol. XVI. No. 2 Oktober 2018}


activity was to find out the feasibility of the developed media to be able to use in real learning. In addition, this validation activity could also provide input on improvements to the media that have been developed (Awaluddin, 2017). Validation activities in this study included validation by media experts, validation by material experts and validation by potential media users. The validation results of the development of Edmodo-based e-learning media on the subject of Plantae along with the learning tools used in limited trials can be seen in Table 1 below:

\section{Table 1. Result of Product Validation}

\begin{tabular}{|c|c|c|c|c|}
\hline $\begin{array}{l}\mathrm{N} \\
\text { o. }\end{array}$ & $\begin{array}{c}\text { Validat } \\
\text { or }\end{array}$ & Product & Result & $\begin{array}{c}\text { Categ } \\
\text { ory }\end{array}$ \\
\hline 1. & $\begin{array}{l}\text { Media } \\
\text { expert }\end{array}$ & $\begin{array}{l}\text { Edmodo- } \\
\text { based } \\
\text { learning } \\
\text { media }\end{array}$ & 86,11 & Good \\
\hline \multirow[t]{6}{*}{2.} & \multirow[t]{6}{*}{$\begin{array}{l}\text { Materi } \\
\text { expert }\end{array}$} & Plantae & 93,18 & $\begin{array}{l}\text { Very } \\
\text { good }\end{array}$ \\
\hline & & Syllabus & 90,62 & $\begin{array}{l}\text { Very } \\
\text { good }\end{array}$ \\
\hline & & $\begin{array}{l}\text { Learning } \\
\text { preparati } \\
\text { on }\end{array}$ & 86 & Good \\
\hline & & $\begin{array}{l}\text { Student } \\
\text { discussio } \\
n \\
\text { workshee } \\
t\end{array}$ & 84,16 & Good \\
\hline & & $\begin{array}{l}\text { Pretest/P } \\
\text { osttest }\end{array}$ & 90 & $\begin{array}{l}\text { Very } \\
\text { good }\end{array}$ \\
\hline & & Quiz & 95 & $\begin{array}{l}\text { Very } \\
\text { good }\end{array}$ \\
\hline 3. & Users & $\begin{array}{l}\text { Edmodo- } \\
\text { based e- } \\
\text { learning } \\
\text { media }\end{array}$ & 90,62 & $\begin{array}{l}\text { Very } \\
\text { good }\end{array}$ \\
\hline
\end{tabular}

Based on the results of the validation by the validator in Table 1, it was known that the results of material validation, user validation, syllabus, pretest/posttest questions, and quiz questions produced very good validity. While the results of media validation, lesson plans, and student discussion sheets produced a good level of validity. If the results of the validation test reach good quality $(80<\mathrm{B} \leq 90)$ then it is necessary to do further development by adding things that were lacking, making certain considerations, additions, etc. (Purwaningsih, 2017). This meant that it was necessary to revise Edmodo-based e- learning media, RPP, and student discussion sheets. After carrying out the validation stage, the next step was to revise the product before used in a field trial based on the validation results and suggestions and comments on the product.

The fourth stage in this study was limited scale trials (field trials). This trial took place at SMAN 2 Jember with three meetings face-to-face, on January 24February 7, 2018 and at SMAN 4 Jember one time face-to-face on February 14, 2018. The purpose of limited-scale trial activities was to determine student assessment of media developed. The results of the assessment at this stage were in the form of assessing the feasibility of content, presentation, and language. In this limitedscale trial phase, the effectiveness and practicality of the product were tested.

The effectiveness test aimed to determine the extent of the effectiveness of the media that has been developed by involving prospective media users (Sari, et.al., 2016). The calculation of effectiveness of the developed Edmodo-based e-learning media was to compare the value of the pretest and posttest students who then calculated them using Normalized Gain (NGain) formula. Normalized gain is a conditional statistical probability that shows how many mistakes students have successfully corrected during the learning process (Mahdianur, et.al., 2016). The average results of product effectiveness test for developed Edmodo-based e-learning media on the subject of Plantae can be seen in Table 2 below:

Table 2. A result of Product's Effectivity Test

\begin{tabular}{cccccc}
\hline \multirow{4}{*}{ School } & \# of & Pret & Post & $N-$ & \\
& stud & est & est & Gai & Categ \\
& ents & (Avg & (Av & $n$ & ory \\
& & (Av & g) & g) & \\
\hline
\end{tabular}

Bioedukasi Vol. XVI. No. 2 Oktober 2018 


\begin{tabular}{|c|c|c|c|c|c|}
\hline SMA & & 37,5 & & & \\
\hline $\begin{array}{l}\mathrm{N} 2 \\
\text { Jembe } \\
\mathrm{r}\end{array}$ & 36 & $\begin{array}{c}3 \pm \\
12,4 \\
8\end{array}$ & $\begin{array}{c}85 \pm \\
11,0 \\
2\end{array}$ & $\begin{array}{c}0,16 \\
\pm \\
0,18\end{array}$ & High \\
\hline $\begin{array}{l}\text { SMA } \\
\mathrm{N} 4 \\
\text { Jembe } \\
\text { r }\end{array}$ & 34 & $\begin{array}{c}44,9 \\
4 \pm \\
13,5 \\
2\end{array}$ & $\begin{array}{c}91,2 \\
9 \pm \\
8,83\end{array}$ & $\begin{array}{c}0,84 \\
\pm \\
0,15\end{array}$ & High \\
\hline
\end{tabular}

Overall, the effectiveness test at SMAN 2 Jember produced an $\mathrm{N}$-Gain value of 0.76 and in SMAN 4 Jember the N-Gain value was 0.84 with the same category, which was the high category. This showed that Edmodo-based e-learning media has a high value of effectiveness on student learning outcomes. The greater the difference between the pretest and posttest scores, the greater the $\mathrm{N}$-Gain value was generated, this indicated that the greater the positive effect of the use of Edmodo-based e-learning media on student learning outcomes. A use of learning media can be effective if planned competencies and learning objectives can be achieved (Susilana, et.al., 2016). Achieving competencies and learning objectives can be identified through student learning outcomes. This is because learning outcomes are a change in behavior that occurs as a result of the ongoing learning process that is carried out in accordance with planned goals (Djiwandono, 2015).

Edmodo-based e-learning media can be effective in improving learning outcomes due to several factors, including the development of this media based on the characteristics of the material being learned and student characteristics. Edmodo-based e-learning media can visualize Plantae's subject matter more varied, either through pictures or learning videos so students don't get bored easily. The use of the same media will cause students to tend to be bored while varying media use will make students remain concentrated and motivated (Mubarok, 2018).

While in terms of student characteristics, Edmodo-based e-learning media is in accordance with the characteristics of students who in everyday life always use information technology tools. In addition, this media is also effective because, in its use, it involves many students so that learning does not become monotonous and students are not easily bored. Student involvement in learning makes students more active and learning becomes more memorable (Wahyu, et.al., 2013).

In addition to the effectiveness test, at the end of limited-scale trial activities, we carried out practical tests. Media consistency testing was carried out by spreading the questionnaire responses to teachers and students. The value of practicality of the media developed can be known through assessment by user or users (Hafiz, 2013). In this case, what is meant by users is students and teachers, through the distribution of questionnaires responses to teachers and students, they can find out the value of practicality of a media. The practicality test results can be seen in the following Table 3 and Table 4:

Table 3. A result of Practicality Test Based on Students Respond

\begin{tabular}{|c|c|c|c|c|c|}
\hline \multirow{2}{*}{$\begin{array}{l}\mathbf{N} \\
\mathbf{o} \\
\cdot\end{array}$} & \multirow[b]{2}{*}{ Statements } & \multicolumn{2}{|c|}{$\begin{array}{c}\text { SMAN } 2 \\
\text { Jember }\end{array}$} & \multicolumn{2}{|c|}{$\begin{array}{c}\text { SMAN } 4 \\
\text { Jember }\end{array}$} \\
\hline & & $\begin{array}{l}\text { Avg. } \\
(\%)\end{array}$ & $\begin{array}{c}\text { Categ } \\
\text { ory }\end{array}$ & $\begin{array}{c}\text { Avg } \\
\dot{(\%)}\end{array}$ & $\begin{array}{c}\text { Categ } \\
\text { ory }\end{array}$ \\
\hline $\begin{array}{l}1 \\
.\end{array}$ & $\begin{array}{l}\text { The } \\
\text { simplicity } \\
\text { of the } \\
\text { menus }\end{array}$ & 85,41 & $\begin{array}{c}\text { Strong } \\
\text { ly } \\
\text { agree }\end{array}$ & $\begin{array}{c}83,2 \\
5\end{array}$ & $\begin{array}{c}\text { Strong } \\
\text { ly } \\
\text { agree }\end{array}$ \\
\hline 2 & $\begin{array}{l}\text { The use of } \\
\text { Edmodo- } \\
\text { based e- } \\
\text { learning } \\
\text { media }\end{array}$ & 86,75 & $\begin{array}{c}\text { Strong } \\
\text { ly } \\
\text { agree }\end{array}$ & 82,5 & $\begin{array}{c}\text { Strong } \\
\text { ly } \\
\text { agree }\end{array}$ \\
\hline $\begin{array}{l}3 \\
.\end{array}$ & $\begin{array}{l}\text { The } \\
\text { practicality } \\
\text { of Exercise } \\
\text { Items }\end{array}$ & 87,37 & $\begin{array}{c}\text { Strong } \\
\text { ly } \\
\text { agree }\end{array}$ & 76 & Agree \\
\hline 4 & $\begin{array}{l}\text { The } \\
\text { practicality } \\
\text { of Quiz } \\
\text { Items }\end{array}$ & 85,5 & $\begin{array}{l}\text { Strong } \\
\text { ly } \\
\text { agree }\end{array}$ & $\begin{array}{c}86,2 \\
5\end{array}$ & $\begin{array}{c}\text { Strong } \\
\text { ly } \\
\text { agree }\end{array}$ \\
\hline $\begin{array}{l}5 \\
.\end{array}$ & $\begin{array}{l}\text { Convenien } \\
\text { ce of } \\
\text { Communic } \\
\text { ation }\end{array}$ & 82,12 & $\begin{array}{c}\text { Strong } \\
\text { ly } \\
\text { agree }\end{array}$ & $\begin{array}{c}76,1 \\
2\end{array}$ & Agree \\
\hline $\begin{array}{l}6 \\
.\end{array}$ & $\begin{array}{l}\text { Students } \\
\text { learning } \\
\text { motivation }\end{array}$ & 83,67 & $\begin{array}{c}\text { Strong } \\
\text { ly } \\
\text { agree }\end{array}$ & $\begin{array}{c}81,7 \\
5\end{array}$ & $\begin{array}{c}\text { Strong } \\
\text { ly } \\
\text { agree }\end{array}$ \\
\hline $\begin{array}{l}7 \\
.\end{array}$ & $\begin{array}{l}\text { Influence } \\
\text { on material } \\
\text { assignment }\end{array}$ & 80,25 & $\begin{array}{c}\text { Strong } \\
\text { ly } \\
\text { agree }\end{array}$ & $\begin{array}{c}77,2 \\
5\end{array}$ & Agree \\
\hline
\end{tabular}

Bioedukasi Vol. XVI. No. 2 Oktober 2018

Received 8 August 2018 | Received in revised form 7 September 2018 | Accepted 21 September 2018 | Published online 1 October 2018 


\begin{tabular}{|c|c|c|c|c|c|}
\hline \multirow{2}{*}{$\begin{array}{l}\mathbf{N} \\
\mathbf{o} \\
\cdot\end{array}$} & \multirow[b]{2}{*}{ Statements } & \multicolumn{2}{|c|}{$\begin{array}{c}\text { SMAN } 2 \\
\text { Jember }\end{array}$} & \multicolumn{2}{|c|}{$\begin{array}{c}\text { SMAN } 4 \\
\text { Jember }\end{array}$} \\
\hline & & $\begin{array}{l}\text { Avg. } \\
(\%)\end{array}$ & $\begin{array}{c}\text { Categ } \\
\text { ory }\end{array}$ & $\begin{array}{c}\text { Avg } \\
\dot{(\%)} \\
\end{array}$ & $\begin{array}{c}\text { Categ } \\
\text { ory }\end{array}$ \\
\hline & $\begin{array}{l}\text { Result } \\
\text { Avg. }\end{array}$ & $\begin{array}{r}84,44 \\
\pm 2,51\end{array}$ & $\begin{array}{c}\text { Stron } \\
\text { gly } \\
\text { agree }\end{array}$ & $\begin{array}{c}80,4 \\
4 \pm \\
3,7\end{array}$ & $\begin{array}{c}\text { Stron } \\
\text { gly } \\
\text { agree }\end{array}$ \\
\hline
\end{tabular}

Overall, the practicality test based on the questionnaire responses from 36 respondents of SMAN 2 Jember resulted in a mean percentage of $84.44 \%$ with the category of strongly agreeing. Similar result gained from 34 respondents of SMAN 4 Jember with an average percentage of $80.44 \%$ in the category of strongly agree. This showed that Edmodo-based e-learning media on the subject of Plantae was practical or easy to use by students.

Table 4. The result of Practicality Test Based on Teacher Respond

\begin{tabular}{|c|c|c|c|c|c|}
\hline \multirow[b]{2}{*}{$\begin{array}{l}\mathbf{N} \\
\mathbf{0 .}\end{array}$} & \multirow[b]{2}{*}{$\begin{array}{l}\text { Statement } \\
\text { s }\end{array}$} & \multicolumn{2}{|c|}{$\begin{array}{c}\text { SMAN } 2 \\
\text { Jember }\end{array}$} & \multicolumn{2}{|c|}{$\begin{array}{c}\text { SMAN } 4 \\
\text { Jember }\end{array}$} \\
\hline & & $\begin{array}{l}\text { Res } \\
\text { ult( } \\
\%)\end{array}$ & $\begin{array}{c}\text { Catego } \\
\text { ry }\end{array}$ & $\begin{array}{c}\text { The } \\
\text { resul } \\
\text { t } \\
(\%) \\
\end{array}$ & $\begin{array}{c}\text { Categ } \\
\text { ory }\end{array}$ \\
\hline 1. & $\begin{array}{l}\text { The } \\
\text { simplicity } \\
\text { of the } \\
\text { menus }\end{array}$ & 75 & Agree & $\begin{array}{c}83,3 \\
3\end{array}$ & $\begin{array}{c}\text { Strong } \\
\text { ly } \\
\text { Agree }\end{array}$ \\
\hline 2. & $\begin{array}{l}\text { The use of } \\
\text { Edmodo- } \\
\text { based e- } \\
\text { learning } \\
\text { media }\end{array}$ & $\begin{array}{c}83,3 \\
3\end{array}$ & $\begin{array}{c}\text { Strongl } \\
y \\
\text { Agree }\end{array}$ & $\begin{array}{c}83,3 \\
3\end{array}$ & $\begin{array}{c}\text { Strong } \\
\text { ly } \\
\text { Agree }\end{array}$ \\
\hline 3. & $\begin{array}{l}\text { Simplicity } \\
\text { in } \\
\text { Assessing }\end{array}$ & 100 & $\begin{array}{c}\text { Strongl } \\
y \\
\text { Agree }\end{array}$ & $\begin{array}{c}83,3 \\
3\end{array}$ & $\begin{array}{c}\text { Strong } \\
\text { ly } \\
\text { Agree } \\
\end{array}$ \\
\hline 4. & $\begin{array}{l}\text { Advantage } \\
\text { s of } \\
\text { Edmodo- } \\
\text { based e- } \\
\text { learning } \\
\text { media }\end{array}$ & $\begin{array}{c}84,3 \\
7\end{array}$ & $\begin{array}{c}\text { Strongl } \\
y \\
\text { Agree }\end{array}$ & $\begin{array}{c}84,3 \\
7\end{array}$ & $\begin{array}{c}\text { Strong } \\
\text { ly } \\
\text { Agree }\end{array}$ \\
\hline 5. & $\begin{array}{l}\text { Opportunit } \\
\text { ies for the } \\
\text { use of } \\
\text { Edmodo- } \\
\text { based e- } \\
\text { learning } \\
\text { media }\end{array}$ & 87,5 & $\begin{array}{c}\text { Strongl } \\
y \\
\text { Agree }\end{array}$ & $\begin{array}{c}81,2 \\
5\end{array}$ & $\begin{array}{c}\text { Strong } \\
\text { ly } \\
\text { Agree }\end{array}$ \\
\hline & $\begin{array}{l}\text { Result } \\
\text { Aveg. }\end{array}$ & $\begin{array}{c}86,0 \\
4 \pm \\
3,62 \\
\end{array}$ & $\begin{array}{c}\text { Strongl } \\
y \\
\text { Agree }\end{array}$ & $\begin{array}{l}83,1 \\
25 \pm \\
1,02 \\
\end{array}$ & $\begin{array}{c}\text { Strong } \\
\text { ly } \\
\text { Agree }\end{array}$ \\
\hline
\end{tabular}

Overall, the practicality test based on the questionnaire responses from teachers of SMAN 2 Jember resulted in a percentage of $86.04 \%$ with the response category strongly agreeing. While the practicality test result from teachers of SMAN 4 Jember produced a percentage of $83.125 \%$ with the response category strongly agree.

A learning media is considered to have high practicality if it is easy to operate and effective in achieving learning goals (Riyana, 2012). Syaifudin (2012) stated that practical learning media is a media that is easy to obtain and easy to use, and in its use does not cost money and can be used whenever and wherever. The developed Edmodo-based e-learning media was considered to be practical based on questionnaire because it is easy to use, able to increase student's learning enthusiasm, and can be used anytime anywhere without spending a lot of money.

The fifth stage in this research was the revision of the overall product based on the validation and field trials result. Product revision is a product improvement process after obtaining input from the results of validation and trial activities in the field. In this study, the authors made revisions at each stage of implementation (Widodo and Jasmadi, 2008).

In the field test activities, there are several obstacles during the learning process in the use of Edmodo-based e-learning media. One of trial process advantage is one can find out the shortcomings of the media that have been developed. During the limited scale trial phase, the product was being revised every time after it was done to use in learning face to face. The overall revision of the product ensures the validity or feasibility of a product because this stage has passed a series of testing stages (Setyosari, 2010).

\section{CONCLUSION}

This development research process used the development model of Borg and Gall (1983) which has been modified by Sugiyono (2006), covering the stages of problem analysis (need analysis), initial product development, expert validation, field testing, and final revision so that the final product will be obtained.

\section{Bioedukasi Vol. XVI. No. 2 Oktober 2018}


The results of Edmodo-based elearning media validation test was 86.11, material validation was 93.18 , media user validation was 90.62 , syllabus validation was 90.61 , lesson plan validation was 86 , validation of Student Discussion Sheet was 84.167, question validation Pretest/Posttest was 90 , and quiz validation was 95 . In general, the entire product development of Edmodo-based e-learning media has a good level of validity and can be used in real learning.

E-learning media with Edmodo on the subject of Plantae has a high effectiveness with an average value of $\mathrm{N}$-Gain obtained at SMAN 2 Jember at 0.76 and at SMAN 4 Jember at 0.84 . The practicality test for students yielded a percentage of $84.44 \%$ and $80.44 \%$. The practicality test for teachers yielded a percentage of $86.04 \%$ and $83.125 \%$. The results of the questionnaire stated that Edmodo-based e-learning media had a very good level of practicality.

\section{REFERENCE}

Awalludin. 2017. Pengantar Bahasa Indonesia untuk Perguruan Tinggi. Yogyakarta: Deepublish.

Aminah, S. 2018. Efektivitas Metode Eksperimen dalam Meningkatkan Hasil Belajar Pada Pembelajaran Ilmu Pengetahui di Sekolah Dasar. Jurnal Indagri. 1(4): $28-80$.

Djiwandono, P. I. 2015. Meneliti Itu Tidak Sulit: Metodologi Penelitian Sosial dan Pendidikan Bahasa. Yogyakarta: Deepublish.

Dwiraharja, L.M. 2015. Memanfaatkan Edmodo Sebagai Media Pembelajaran Akuntansi. Prosiding Seminar Nasional. 09 Mei 2015.

Falahudin, I. 2014. Pemanfaatan Media dalam Pembelajaran. Jurnal Lingkar Widyaiswara. 1 (4): 104 - 117.
Haviz, M. 2013. Research And Development: Penelitian di Bidang Kependidikan yang Inovatif, Produktif dan Bermakna. 2013. Jurnal Ta'dib. 16 (1): $28-43$.

Irfandi. 2015. Pengembangan Model Latihan Sepak Bola dan Bola Voli. Yogyakarta: Deepublish.

Mahdiannur, M. A., M. Nur, Z. A. I. Supardi. 2016. Dinamika Pemahaman Konsep Siswa SMP pada Materi Energi Normalized Gain Versus Normalized Loss. Jurnah Pendidikan Sains Pascasarjana Universitas Negeri Surabaya. 5 (2): 991 - 1000.

Mubarrok, H. 2017. Ketika Guru dan Siswa Saling Berbincang. Jakarta: PT Alex Media Komputindo.

Purwaningsi, R. D. 2017. Pengembangan Perangkat Pembelajaran Kontekstual Terintegrasi Game The Banna Pada Pokok Materi Ekosistem dalam Meningkatkan Motivasi dan Hasil Belajar Kognitif IPA Biologi SMP. Skripsi. Jember: Program Studi Pendidikan Biologi Jurusan Pendidikan MIPA Fakultas Keguruan dan Ilmu Pendidikan Universitas Jember.

Riyana, Cepy. 2012. Media Pembelajaran. Jakarta: Direktorat Pendidikan Islam Kementriam Agama Republik Indonesia.

Saifuddin. 2014. Pengelolaan Pembelajaran Teoretis dan Praktis. Yogyakarta: Deepublish.

Sari, L. Y. dan D. Susanti. 2016. Uji Efektivitas Media Pembelajaran Interaktif Beroreientasi Konstruktivisme pada Materi Neurulasi untuk Perkuliahan Perkembangan Hewan. Jurnal BioCONCETTA. 2 (1): $2460-8556$.

\section{Bioedukasi Vol. XVI. No. 2 Oktober 2018}


Seragih, J. F. B. 2012. Fenomena Bermain Generasi $\mathrm{Z}$ dan Hubungannya dengan Eksistensi Ruang Bermain Terbuka di Lingkungan Perumahan Sederhana. Jurnal ComTech. 3 (1): 8 - 14.

Setyosari, P. 2010. Metode Penelitian Pendidikan Pengembangan. Jakarta: Kencana Prenada Media Group.

Setyosari, P. 2013. Metode Penelitian Pendidikan dan Pengembangan. Jakarta: Prenadamedia Group.

Sugiyono. 2006. Metode Penelitian Pendidikan: Pendekatan Kuantitatif, Kualitatif, dan $\mathrm{R}$ dan $\mathrm{D}$. Bandung: Alfabeta.

Susilana, R. dan C. Riyana. 2009. Media Pembelajaran: Hakikat, Pengembangan, Pemanfaatan dan Penilaian. Bandung: CV Wacana Prima.

Suyanto, A.H. 2015. Pengenalan ELearning. http://www.jurnalkomputer.com. [Diakses pada 21 November 2017]

Utomo, D.S., Sumarmi., S. Susilo. 2015. Pengembangan Bahan Ajar E-learning Berbasis Edmodo pada Materi Litosfer Kelas X SMA. Jurnal Pendidikan Geografi. 20 (2): 1 - 8.

Wahyu, D., I. Z. Mahmudah., I. Nurfatonah., P. F, Quraesin. 2013. Mengembangkan Kemampuan Bercerita Siswa Sekolah Dasar dengan Menggunakan Metode Paired Storytelling. Seminar Nasional Pendidikan Dasar: 69 - 74 .

Widodo, C.S. dan Jasmadi. 2008. Panduan Menyusun Bahan Ajar Berbasis Kompputer. Jakarta: PT Alex Media Komputindo.

\section{Bioedukasi Vol. XVI. No. 2 Oktober 2018}

